\title{
Ernst Hofer: A German Republican Journalist in Iowa, 1855-1890
}

\section{ROLF SWENSEN}

DURING THE 1880s, Ernst Hofer was a controversial figure in Iowa politics and journalism, yet during the intervening century his name has completely dropped from sight. One of the most flamboyant Republican journalists of his day, Hofer edited the family-owned McGregor News from 1878 to 1889 and his own German-language weekly, the Iowa Staats-Zeitung in Des Moines from 1886 to 1888 . Governor William Larrabee characterized him as a "student of men, methods, and events, [whose] spicy writings are always read with great interest." ${ }^{\prime 1}$ Energetic and sometimes abrasive, Hofer embraced prohibition and other causes from the conviction that various forces threat-

I would like to thank the following people for assisting with this article: the late Mrs. Allan A. Bynon of Lake Oswego, Oregon, daughter of Ernst Hofer; Lida Lisle Green and Lowell Wilbur, former librarians of the State Historical Society of Iowa, Des Moines; Mrs. Fred Huebsch, director of the McGregor Historical Museum; Henry Follett, site manager of Montauk, the Larrabee mansion at Clermont; Jean Welsh, Clayton County Recorder; Helen Frieden, Fayette County Recorder; Elvin J. Johnson and Arnold Roggman of Garnavillo; Ken P. Johnson, archivist of the Garnavillo Historical Society; Anita Cox, director of the Elkader Public Library; and Robert McCown, head of Special Collections, University of Iowa Libraries. Thanks should also go to Gordon O. Hendrickson, Iowa State Archivist, and Ron Moore, former head of the Iowa Newspaper Project, for microfilming the North Iowa Times of McGregor for 1872-1888. I am also grateful to John Yates of McGregor for taking several photographs of items in the McGregor Historical Museum. Matthew Simon, chief librarian of Rosenthal Library, Queens College, City University of New York, critiqued the manuscript. This article had its genesis in a doctoral dissertation at the University of Oregon under the tutelage of Dr. Edwin R. Bingham and Dr. Leslie E. Decker.

1. William Larrabee to "Whom it May Concern," 24 December 1889, Governor Letter Book, 8 January 1889-4 February 1890, Series GII, vol. 80, p. 892, State Historical Society of Iowa, Des Moines.

THE ANNALS OF IOWA 51 (Fall 1992). (CThe State Historical Society of Iowa, 1992. 
ened individual opportunity and the sanctity of American life, as well as from opportunistic motives born of economic hardship.

More than just a colorful personality grappling with weighty issues, Hofer's life and career provide insights into Iowa politics and journalism in the 1870 s and 1880 s, particularly in the northeast portion of the state. Cyrenus Cole has described Iowa journalism during the Gilded Age as "personal and political," as well as "partisan and opinionated." The most visible Iowa journalist of the age was James S. Clarkson, editor of the Iowa State Register in Des Moines, who functioned as the "journalistic and political dictator" of the state Republican party. There were other noteworthy newspapermen, including Samuel Mercer Clark of the Keokuk Gate City, known as the "Master Stylist of the Iowa Press," and George D. Perkins of the Sioux City Journal, who impressed readers with his logical arguments. Hailing from a relatively unimportant city in a part of the state increasingly known for its fractiousness and Democratic ascendancy, Hofer's biting rhetoric caught the attention of Republican party leaders and propelled him onto center stage. Unfortunately, much of that rhetoric disappeared with the destruction decades ago of all but three years (1887-1889) of the McGregor News and every issue of the Staats-Zeitung, but enough has survived in other Iowa newspapers of the timeand in letters, state and county records, and other sources-to recreate much of Hofer's life and work. ${ }^{2}$

IN 1855, the year of Hofer's birth, Iowa was booming, as the editor of the Dubuque Reporter enthusiastically noted. "Viewing the almost countless throng of immigrants that crowd our streets, and learning that a similar scene is visible at every other point along the Mississippi border of Iowa, the spectator is naturally led to infer that a general exodus is taking place in the Eastern states of the Union, as well as in those that, but a few

2. Cyrenus Cole, Iowa Through the Years (Iowa City, 1940), 331-32, 397-98. The McGregor Historical Museum holds the only known copies of the McGregor News, a bound volume containing the issues of 2 February-7 September 1887 and 9 November $1887-29$ October 1889. Included is a partial issue from ca. November 1886. 
years ago, were denominated the West." This "incoming human flood" helped swell the population of the state from 326,500 in 1854 to 512,000 just two years later. Many of these new arrivals were foreign-born; by 1860 Iowa contained thousands of Germans, Irish, English, and Scandinavians. Despite these foreign immigrants, settlers from the eastern states - particularly New England-were much more numerous. "The immigration of the fifties," concludes Cole, "changed the social, educational, and political conditions in Iowa." Traffic on the Mississippi River was the "heaviest it ever was," while the first railroad in the state was constructed between Davenport and Iowa City in 1855-1856. Iowa, the "emerald sea," was awakening to a rush of people. "Let them come!" cried the editor of the Keokuk Whig to all prospective immigrants. ${ }^{3}$

One of those who responded was Ernst Hofer's father, Andreas Franz (A. F.) Hofer, who arrived in Dubuque with his young wife during a snowstorm in March 1855. A carpenter and musician by trade and a viticulturist by avocation, A. F. Hofer was born in 1821 in Oehnsbach, Grand Duchy of Baden. Because of his participation in the revolutions of 1848-1849, he had to flee to Switzerland. Disembarking in New York City after a harrowing sea voyage in November 1849, he found work as a carpenter. Four years later he married Mari Ruef, who had recently left Germany with her parents. The couple soon moved to Saugatuck, Connecticut, where A. F. Hofer was employed as a pattern maker in a car spring factory. Dissatisfied with his chances in the East and anxious to join friends in Iowa, he headed west with his wife and her parents and brother Julius early in 1855. "Such a romantic and picturesque succession of trekkings," Ernst Hofer later wrote, "could but produce a romantic and picturesque individual and enterprising but restless offspring." ${ }^{4}$

3. Dubuque Reporter, quoted in N. Howe Parker, Iowa as It Is in 1855 (Chicago, 1855), 55; Morton Rosenberg, Iowa on the Eve of the Civil War: A Decade of Frontier Politics (Norman, OK, 1972), 24; Leland L. Sage, A History of Iowa (Ames, 1974), 92-96; Cole, Iowa through the Years, 215; Realto E. Price, ed., History of Clayton County, Iowa, 2 vols. (Chicago, 1916) 1:241; Keokuk Whig, quoted in Iowa as It Is in 1855, 59.

4. History of Clayton County, Iowa (Chicago, 1882), 391-92; Amalie Hofer Jerome, My Century: The Story of Andreas Franz Hofer (Boston, 1937), 13-126 
Ernst was born in Dubuque on September 1, 1855, the first of eight siblings. A. F. Hofer worked briefly at a local sash and door factory, but soon became the last member admitted to the ailing German socialist commune known as Communia, which the Ruefs had already joined. Located about fifty miles northwest of Dubuque, Communia in fact had been the Hofers' original destination, but they had run out of money in Dubuque. While at Communia, Hofer plied his carpentry skills, arranged and composed music, played both violin and clarinet in the communal orchestra, and may have become a radical free thinker. However brief, the Hofers' association with Communia was a formative influence in the lives of A. F. and Ernst Hofer, for both father and son later held strong views against socialism and communism. ${ }^{5}$

After the demise of Communia and following recovery from a "dangerous hemorrhage of the lungs," A. F. Hofer moved his family a few miles "over the hills" in 1858 to Littleport on the Volga River, where he built a log cabin. Their dwelling was the first-structure in the newly platted town, which was owned by Dennis Quigley, a trustee of the defunct Communia. At Littleport, Hofer manufactured grain vinegar (and perhaps more potent liquids), bought and sold land, served as clerk of Cox Creek Township from 1859 to 1861, and was active in the Republican party. Littleport was in an especially attractive part of Iowa, for many rivers cut deep channels through rolling hills covered with hickory and pine. There Ernst spent his early childhood. With the coming of the American Civil War in 1861, Ernst's father helped organize and served as second lieutenant of Company E, Ninth Iowa Volun-

(this rare volume is based on diaries and other primary sources, which have apparently vanished); E. Hofer, "The Honeymoon," The Lariat 1 (July 1923), 251. "The Honeymoon," Hofer's reminiscences of his Iowa years, was serialized in his "little literary magazine," the Lariat, February 1923-March 1924.

5. Lariat 1 (February 1923), 47; Lariat 2 (September 1923), 336; Edgar R. Harlan to Hofer, 18 November 1914, and Hofer, "Outline of Personal History," 23 November 1914, State Historical Society of Iowa, Des Moines; Jerome, My Century, 127-35; History of Clayton County, Iowa (1882), 392-93; Communia Day Book, 1853-1856, and receipt by Henry M. Jones, 13 June 1859, Clayton County Courthouse, Elkader; Lariat 1 (July 1923), 250; Elkader Register, 17 June 1885. On Communia, see H. Roger Grant, "Utopia at Communia," Palimpsest 61 (1980), 12-17. 
teers. After six months of service in Missouri, he came home "sick and discouraged" following a bout with "swamp fever." 6

In 1862 the Hofers moved to Clermont, a larger and more prosperous town located on the Turkey River northwest of Littleport. "It was a long all-day ride of about thirty miles," Ernst later remembered. "We forded creeks and at times the water filled the wagon box." At Clermont his father ran a general store, served two terms as township assessor, was active in Republican politics, led a quadrille band, and, through the influence of State Senator William Larrabee, was appointed sergeant-at-arms of the Iowa state senate for two sessions. Many years later, A. F. Hofer wrote to Larrabee that "taking me to Des Moines was the best schooling I ever received." Ernst had a variety of jobs: he worked in Larrabee's cooperage, harvested crops, apprenticed with a blacksmith, and traveled by riverboat to join a railroad surveying crew in Hannibal, Missouri. Although he put in long hours to help family finances, Ernst had time to trap mink and muskrat, swim, and play baseball. $^{7}$

While living at Clermont, A. F. Hofer also operated a vinegar factory, prompting the editor of the West Union Republican Gazette to predict that "when Clermont gets the railroad, Frank [A. F. Hofer] will go to work and make a fortune with his sour stuff. Hope he may." By 1870, Hofer's wealth was listed in the United States Census as five thousand dollars in personal property-a considerable sum in that day. He was an active speculator in real estate, as he had been in Littleport, but in 1871 and 1872, he began disposing of many of his holdings. By the end of 1872, Hofer, together with members of the Ruef family, had sold land in Clermont totaling two thousand dollars in value. Hofer may have been trying to raise money for further

6. Lariat 2 (September 1923), 336; Clayton County Journal, 18 April, 2 May 1861; Deed Record, Town Lots, Book 4, Clayton County Courthouse; History of Clayton County, Iowa (1882), 393. For perspective, see Rosenberg, Iowa on the Eve of the Civil War.

7. Lariat 2 (September 1923), 338; Lariat 2 (December 1923), 451; Lariat 3 (March 1924), 84-85; Jerome, My Century, 174-80; History of Clayton County, Iowa (1882), 393; A. F. Hofer to Larrabee, 21 December 1901, Larrabee Papers, Montauk, Clermont, Iowa. On Larrabee, see Cole, Iowa Through the Years, 213, 370-71. 
investments - perhaps for one of the two railroads then making their way to Clermont-or he may have needed to pour money into his vinegar factory after it was nearly leveled by a storm. For whatever reason, something went wrong, and Hofer decided to leave Clermont. According to a correspondent of the Fayette County Union, Hofer ascribed his departure to "family affairs," while a contemporary history referred to his "unfortunate speculations." Ernst Hofer later recollected that his father had incurred a "heavy debt."

On August 23, 1872, Ernst's parents and five sisters hurriedly left Clermont "by means of Hezekiah Frizbie's high wheeled stage" for McGregor, about thirty miles to the east. Ernst, together with his grandmother Ruef and his two brothers, had set out the previous day in a wagon pulled by their "gray mare Fanny" and accompanied by their Jersey cow. Their choice of McGregor was undoubtedly influenced by the presence there of William Larrabee's brother Frank, who became president of the First National Bank of McGregor only two weeks after the Hofers' arrival. Variously described as a "miserable, cooped up place in a ravine" or as the "pent-up Utica of Iowa," McGregor was a small town on the Mississippi River across from the historic settlement of Prairie du Chien, Wiscon$\sin$. There A. F. Hofer struggled to support his family as a carpenter in the summer, working on the ship canal at Muscoda, Wisconsin, teaching music in the winter, and leading another quadrille band. Endowed with strong political convictions, Hofer wrote a series of articles for the independent Peoples Paper of Clermont denouncing railroads and high taxation, and he played a leading role in the organization of the local Greenback party in 1876. In his leisure time Hofer raised grapes on the steep hill behind the family home and later wrote a column on "small fruits" for Coker F. "Father" Clarkson, agricultural editor of the Iowa State Register. Profiting from his financial

8. West Union Republican Gazette, 28 July 1871; Ninth Census of the United States, 1870, Iowa, Fayette County, Clermont Township, 11 (typescript); Town Lot Index \#2, Town Lot Deed Books 4 and 5, Fayette County Courthouse, West Union; Fayette County Union, 28 August 1872; History of Clayton County, Iowa (1882), 393; Lariat 2 (July 1923), 251. 


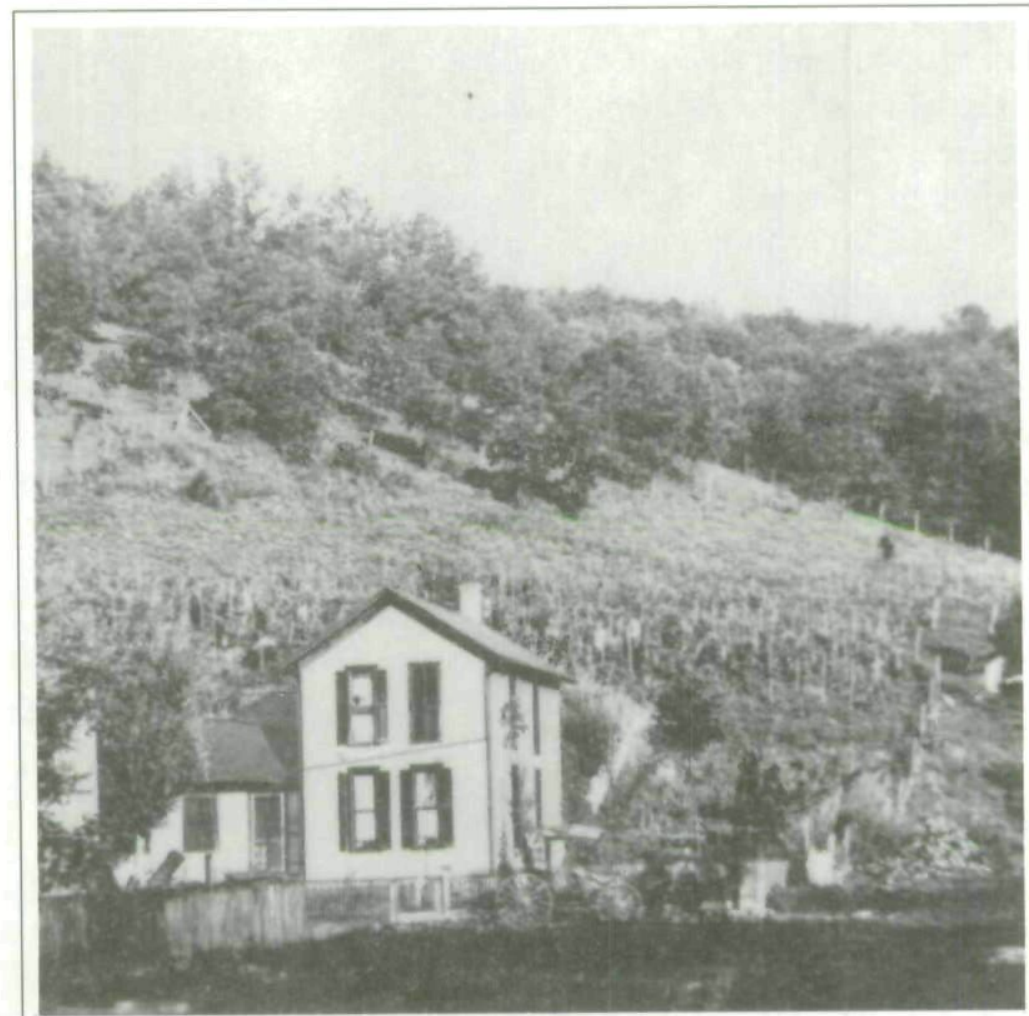

A. F. Hofer house, McGregor, c. 1880. Note the vineyards on the hill. Photo courtesy of McGregor Historical Museum.

imbroglio in Clermont, Hofer entered any land he bought in McGregor under his wife's or children's names. ${ }^{9}$

Ernst helped his father at carpentry and worked as a railroad surveyor for Judge Elias H. Williams of Postville, a brother-in-law of William Larrabee. Exhibiting boundless energy and

9. Jerome, My Century, 180, 185-87; Lariat 1 (April 1923), 128; Lariat 1 (July 1923), 251-52; Iola B. Quigley, "A Metropolis of the Fifties," Palimpsest 12 (1941), 20-33; Diary of George Shipp, quoted in Bessie L. Lyon, "Prospecting for a New Home," Palimpsest 6 (1925), 230; Diary of Jesse Clement, quoted in "Clayton County," Palimpsest 47 (1966), 412; History of Clayton County, Iowa (1882), 393; Price, History of Clayton County, Iowa, 1:232-35; Vinegar Bitters [A. F. Hofer], "The Impending Crisis," Peoples Paper, 5 June 1873; North Iowa Times, 26 October 1876; Iowa State Register, 30 May 1883; Town Lot Deed Book \#13, Clayton County Courthouse. See also Earl S. Beard, "The Background of State Railroad Regulation in Iowa," Iowa Journal of History 51 (1953), 1-36; Fred E. Haynes, Third Party Movements Since the Civil War with Special Reference to Iowa (1916; reprint ed., New York, 1966), chaps. 7 and 12. 
civic pride, Ernst was also an ice hauler, a shipping clerk in a wholesale grocery concern, a member and later chief of the McGregor volunteer fire department, a participant in the local drill team known as the McGregor Rifles, and an enthusiastic player on the local baseball team. There were also family musicales and poetry readings. Ernst often read aloud in English from Shakespeare and in German from the works of the poet and dramatist Friedrich Schiller; he even found time to translate some pieces from German into English for local students. These cultural activities had some interesting results, as Ernst later recalled: "All this [interest in literature] gave me the impulse to throw up a perfectly good job where I was earning $\$ 40$ a month to put into the family pot, bought an armful of books on credit and entered high school as a junior. My parents shed tears and I think regarded me as almost mad." Ernst had not attended school since the elementary grades, but he impressed his principal, Lucy Maynard Salmon, as "naturally very talented [and] remarkably well read," but with an "exalted opinion of his own capabilities." After only two years he graduated from McGregor High School in June 1877 in a class that included Frank Larrabee's daughter Rachel. Reporting on the commencement exercises, the North Iowa Times of McGregor commented that "Ernst Hofer made excellent and sharp hits on 'Journalism,' telling a few facts that went home to the candid mind." This graduation speech was a harbinger of Ernst's future career and a reference to a new turn in the family fortunes. ${ }^{10}$

EFFECTIVE FEBRUARY 7, 1877, the Hofers had purchased an option on the McGregor News, a weekly Republican paper founded in 1859. For many decades A. F. Hofer had dreamed of entering the journalistic field, and wherever he went he had shown a lively interest in politics. Shortly after he left Communia, he had begun to express that interest through the newly formed Republican party. He had cultivated a relation-

10. Lariat 2 (July 1923), 249-53; Lariat 2 (September 1923), 335; Lariat 3 (March 1924), 86; Lucy Maynard Salmon to Pomeroy Salmon, 23 February 1877, Lucy Maynard Salmon Papers, Courtesy of Special Collections, Vassar College Libraries (Salmon later attained fame as professor of history at Vassar from 1887 to 1927); North Iowa Times, 21 June 1877. 
ship with the well-connected Larrabee family that sprouted in Clermont and continued to grow after the Hofers moved to McGregor. During his years of service as sergeant-at-arms of the Iowa state senate, A. F. Hofer undoubtedly came into contact with many influential Republicans. The column he later wrote for the Iowa State Register solidified his relationship with the Clarksons, Iowa's most prominent newspaper family, who occupied the center of power in Republican party politics. In addition, both A. F. and Ernst Hofer maintained a cordial relationship with United States Senator William B. Allison, who lived in Dubuque. A. F. Hofer's involvement with Communia and his flirtation with the Greenback party reflected a streak of reform that was by no means an anomaly among otherwise loyal Iowa Republicans, as James B. Weaver's example illustrates. Unlike Weaver, "whose earnest nature had disposed him first to independence, then to desertion of the Republican 'church' and the embrace of an agrarian radicalism," A. F. Hofer returned in large measure to the Republican fold. In an era when newspapers mediated political power, editing a local newspaper was a natural outlet for men with political interests and connections such as A. F. Hofer and his sons. Ernst, who quickly assumed editorial control of the newspaper, adopted his father's politics of vocal Republicanism tinged with an independent streak. ${ }^{11}$

The Hofers' opening editorial stated, "The political part of the News will be conducted in the interest of the Republican party, but we will fearlessly aim to be right rather than partisan." This was not an unusual statement of principle, but was rarely practiced in an age known for fierce partisanship.

11. Jerome, My Century, 208; A. F. Hofer to Allison, 9 December 1877 and Allison to Hofer, 15 December 1877, William Boyd Allison Papers, State Historical Society of Iowa, Des Moines; Matthew Josephson, The Politicos, 18651896 (New York, 1938), 267. On the Clarksons, see Leland L. Sage, "The Clarksons of Indiana and Iowa," Indiana Magazine of History 50 (1954), 42946. On Allison, see Leland L. Sage, William Boyd Allison: A Study in Practical Politics (Iowa City, 1956). On Weaver, see Sage, A History of Iowa, 196-97; Haynes, Third Party Movements, 165-67; Thomas Burnell Colbert, "Political Fusion in Iowa: The Election of James B. Weaver to Congress in 1878," Arizona and the West 20 (1978), 25-40; and idem, "Disgruntled Chronic Office Seeker or Man of Political Integrity: James Baird Weaver and the Republican Party in Iowa, 1857-1877," Annals of Iowa 49 (1988), 187-207. 
According to Frank Luther Mott, American journalism of the 1870 s was characterized by its "emergence from the domination of party," but "many editors who talked loudly and long about independence were always found toeing the line on partisan issues." The Iowa State Register was then taking umbrage at "Democratic Demonism" in the still unresolved 1876 presidential contest between Samuel J. Tilden and Rutherford B. Hayes. By contrast, A. F. Hofer noted during a visit to the Clayton County Journal in Elkader in June that the Republican Hayes "never was elected." Under the Hofers, the News offered constructive or acidic comments on statewide political races, attacked financial "combinations," lambasted the Democratic party, twitted the Republicans, and advocated woman suffrage. The News also contained local gossip, humorous "funnygraphs," reprinted features, an "Amateurs Column" contributed by such noms de plume as "Incognoramus" and "Voice from the Wilderness," a pamphlet by A. F. Hofer on grape cultivation in the Upper Rhine Valley, and a serialized novel by A. F. and Ernst Hofer titled The Living and the Dead. ${ }^{12}$

At the end of the first year of Hofer proprietorship, the name of the concern was changed to A. F. Hofer \& Sons, to reflect the contributions of Ernst and his two brothers. All of Ernst's seven siblings were involved in the enterprise, but Ernst was the editor-in-fact of the News for most of the family's tenure. The Democratic North Iowa Times of McGregor observed in 1884 that Ernst had been the "editor since the Hofer reign over that frail concern [began]." Ernst himself confirmed this widely held assumption. "We have had to work so hard," he wrote to Senator Allison, "that none have been trained to do the writing that I have to do-nearly all on the paper." That was no idle boast. For example, in 1877, when the News opposed giving

12. Slightly varying versions of the Hofers' opening editorial are reprinted in History of Clayton County, Iowa (1882), 390-91, and in Jerome, My Century, 210; Frank Luther Mott, American Journalism: A History, 1690-1960, 3d ed. (New York 1962), 411, 414; Iowa State Register, 7 February 1877; Clayton County Journal, 6 June 1877. For a detailed description of the News, see Jerome, My Century, 210-30. For an example of editorials in the News, see "Harlan and Allison," reprinted in Iowa State Register, 25 December 1877. See also A. K. Bailey, "Pioneer Editors of Northeastern Iowa," Annals of Iowa 5 (1901), 117-25; and C. Vann Woodward, Reunion and Reaction: The Compromise of 1877 and the End of Reconstruction (Boston, 1951). 
fees collected for licensing saloons to public schools, one "DIsGUSTED REPUBLICAN" wrote to the Democratic North Iowa Times of McGregor that some "innocent fledgling" was producing articles "filled with imbecility." After Judge Samuel Murdock of Garnavillo launched a series of essays titled "Prehistoric Man" the following year for the newly established Democratic Elkader Register, an anonymous News writer brashly accused the judge of thrashing around in the "misty, impractical marshes of a semi-infidelistic mess of incoherence that does no credit to the paper that publishes them." While there is no definite proof of the identity of the "innocent fledgling," the wording of the rebuttals of Judge Murdock's essays bear the unmistakable stamp of Ernst Hofer, who had now made his debut on the Iowa scene. ${ }^{13}$

When local Democratic party stalwart Frank D. Bayless bought the Elkader Register in December 1878, the journalistic fires were kindled in earnest. For the first several weeks under its new owner, the Register ran frequent items from the News without comment, but this apparent bond between a Democratic and Republican paper in the same county was shortlived. When the News charged Democratic county officials with "wishy-washiness" on the subject of officials' salaries, the Register replied, "If there is any one subject that the Hofer's [sic] of the McGregor News know less about than anything else, it is the state laws that govern our county's financial machinery." Bayless did allow, however, that the Hofers were in favor of economy in government. After the News accused the county auditor of pocketing $\$ 200$ - a munificent sum in those daysthe Register cried, "Oh, my! What a display of wisdom and knowledge of law." Journalistic skirmishing also existed between the News and the Republican Clayton County Journal in Elkader, edited by J. W. Shannon. ${ }^{14}$

By the summer of 1879 , the Iowa State Register had dubbed the McGregor News the "leading Republican paper of Clayton

13. Jerome, My Century, 211; North Iowa Times, 7 February 1884; Hofer to Allison, 24 December 1882, Allison Papers; North Iowa Times, 28 September 1877; Elkader Register, 2 May 1878.

14. Elkader Register, 22 May 1879; Clayton County Journal, 14 November 1877. 
county," which must have both elated the Hofers and sobered editor Shannon. The Republican press in northeastern Iowa was by no means unanimous in supporting the activities of the News. Without naming the Hofers or the News, the Independence Bulletin had unleashed a broadside the previous February against "a weekly paper published in this district." Although the proprietor of the Bulletin professed great respect for the editor of said paper, he aimed his admonition at the "younger portion" of the staff. The article continued that the paper in question "furnishes us an example of vehement, incoherent, unreasonable, grovelling and demented partisan and political fanaticism, such, as we believe, is without parallel in the State." The editorial writer of the pilloried paper was "near the verge of imbecility." This stirring piece was reprinted without comment in the Clayton County Journal. Editor John W. Andrick of the North Iowa Times also became exasperated by "dear little Ernst," that "bundle of conceit," who with his father was "one of the 'Smartys."'15

Ernst Hofer did have a lively and acerbic journalistic style, whether he was discussing local, state, or national politics. While his language was just as provocative as James S. Clarkson's, his style was perhaps more emotional than Bayless of the Elkader Register or Andrick of the North Iowa Times, and far more acidic than Shannon of the Clayton County Journal. Predictably, Hofer assailed the national Democratic party for organizing election fraud, sheltering unpatriotic states' rights advocates, and using "rag money" to capitalize on sensational charges. The News championed former Illinois Congressman Elihu Washburne for president in 1880 - particularly after the Iowa State Register called him a "party drone" - but Washburne burst his own political bubble by backing the scandal-tainted former president, Ulysses S. Grant. Undaunted, the irrepressible Hofer joined several colleagues from northeastern Iowa to report on the Republican national convention in Chicago, after which the News backed the Republican nominee, James A. Garfield. In one curious piece featured in the Iowa State Register soon after the 1880 elections, Hofer satirized political hacks, or

15. Iowa State Register, 20 July 1879; Independence Bulletin, reprinted in Clayton County Journal, 26 February 1879; North Iowa Times, 28 October 1880, 3 August 1882. 
"drones," who "live off the labor of others-sponge, deadbeat-call it what you will. Their virtues are like fly-specks on the whitened ceiling of a sepulcher of vices." Such creative political prose might have been aimed at either Washburne or Grant, but whoever the intended object, Hofer delighted his allies and infuriated his adversaries. ${ }^{16}$

The following year, Hofer learned a valuable lesson in hardball politics during William Larrabee's abortive campaign for the gubernatorial nomination. Late in 1880, the News nonchalantly allowed that Buren R. Sherman, a leading contender for the governorship, had a "courteous grace," but that the "politicians know [Larrabee] well enough to fear him and we predict that he is probably to be the man." The next spring, Hofer stated that Larrabee "has never shown any of the spirit of a truckler or time server" and that a "majority of the thinking, conservative business men in the State will support [him]." Presumably, "conservative" meant those people opposed to monopolies and other pernicious economic trends. The Iowa State Register boomed Sherman, however, so the Republican convention narrowly rejected Larrabee in favor of Sherman. Hofer then charged that a "coup d'etat" had deprived Larrabee of the party nod and unjustly given it to Buren Sherman, whom the News deprecated. The North Iowa Times subsequently chortled that James S. Clarkson-powerful editor of the Iowa State Register and alleged head of the state "Regency," or political machine - and his family had turned the 1881 Republican state convention into a "mob for the purpose of defeating Larrabee." While Larrabee's defeat was a political disappointment for Hofer, his personal life took a more hopeful turn: on November 21, 1881, he married Winona McKinnie of McGregor, a former schoolmate whom he had courted for six years. ${ }^{17}$

16. McGregor News, reprinted in Iowa State Register, 13 December 1879 ("rag money" may refer to bribing newspapers, or "rags," but may also mean taunting, or "ragging"), 23 January 1880, 18 December 1880; North Iowa Times, 3 June 1880.

17. McGregor News, reprinted in Iowa State Register, 30 November 1880, 16 April 1881; Iowa State Register, 4 May 1881; McGregor News, quoted in Iowa State Register, 13 July 1881; North Iowa Times, 18 May 1882; Marriage Record, Clayton County, Book O, 14 January 1869-27 December 1883, Clayton County Courthouse; Lariat 1 (July 1923), 252. 
ALREADY the young editor had established strong credentials within the Republican party in Iowa, but positions he took on several issues and candidates in the early 1880 s solidified those credentials. The most volatile political subject in Iowa during that decade was prohibition. In Clayton County, politics "hinged almost entirely upon the question of prohibition," which the Republicans defended as a panacea and the Democrats denounced as an infringement upon personal liberty. Germans had traditionally been staunch Republicans, but during the fiery 1882 campaign over a proposed prohibition amendment to the state constitution, they showed signs of defecting to the Democrats "almost en masse." Clayton County was aflame with political excitement, as both prohibitionists and their adversaries held conventions and decades-old political alliances and friendships dissolved in bitterness. According to historian Richard Jensen, the referendum stirred "beliefs and prejudices stronger and more basic than party loyalty." ${ }^{18}$

Despite his German heritage and his tendency to follow an independent tack, Ernst Hofer supported the proposed prohibition amendment in forceful editorials that Clarkson reprinted in full on the front page of the Iowa State Register. Initially lighthearted, Hofer wondered if J. M. Hagensick's large brewery north of McGregor "would make a splendid plow factory," but decided that since it would be "necessary for all drinking men to keep their own supplies after the Amendment passes, ... a jug factory would be a good thing to start." In one especially cogent piece, Hofer exulted that "instead of great smoky, reeking cities, we [Iowans] have half a million pure-aired country homes and thousands of flourishing villages and incorporated towns." Iowa and its farm families were not totally insulated from impure influences, however, but had to bear the emotional and financial burdens of criminal cases arising from the "liquor traffic" controlled by "foreigners" in "our few large cities." Prohibi-

18. Price, History of Clayton County, 1:240, 241; Richard Jensen, The Winning of the Midwest: Social and Political Conflict, 1888-1896 (Chicago, 1971), 96. See also Dan Elbert Clark, "The History of Liquor Legislation in Iowa, 18781908," Iowa Journal of History and Politics 6 (1908), 503-608; Ballard C. Campbell, "Did Democracy Work? Prohibition in Late Nineteenth-Century Iowa," Journal of Interdisciplinary History 8 (1977), 87-116. 


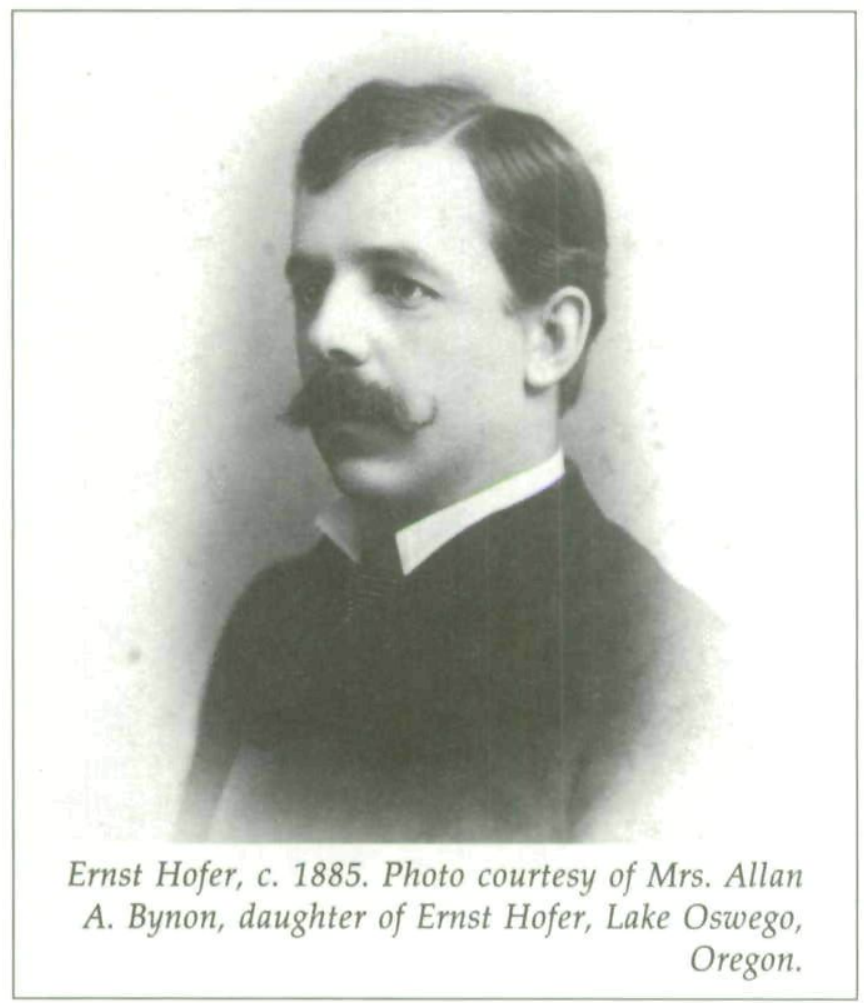

tion would not only keep down government expenses, it would preserve Iowa's rural heritage and the sanctity of the family against incursion by "foreign" elements. In the closing days of the campaign, Hofer claimed that Iowa could enforce prohibition more effectively than Maine or any other state in the Union because it had "no sailors, no lumber men, no sea fishermen, no smugglers, no plantations populated by ignorant halfbreeds." A. F. Hofer used similar rhetoric in several speeches and in a pamphlet, "The Saloon Keeper," which was distributed throughout the state. Such rhetoric helped ensure statewide passage of the prohibition amendment, though by a smaller margin than Republican leaders had anticipated. In Clayton County the amendment lost badly, and many people dropped their subscriptions to the News. ${ }^{19}$

19. McGregor News, reprinted in Iowa State Register, 12 March, 16 June, 24 June 1882; North Iowa Times, 10 August 1882. 
Clarkson, impressed with Ernst Hofer's audacious handling of the thorny prohibition question, asked him to become assistant editor of the Iowa State Register. Although Hofer wanted the job, he advised Senator Allison, "I cannot see my way clear to accept this very flattering offer, because I dare not leave the rest of the family to struggle on with the business and its pecuniary liabilities." Loyalty to his family was not the only reason for Hofer's reluctance to accept the proposition, however. "While the Clarksons make me a flattering offer," he admitted, "it would not much more than keep me and my wife at the Capital." Presumably, if the offer had been more remunerative, Hofer would have accepted it and perhaps sent home part of his salary to McGregor. He asked Allison to persuade Clarkson to wait six months, at which time he could probably accept the position, but Clarkson couldn't or wouldn't wait. ${ }^{20}$

With his immediate fortunes linked to McGregor and its environs, Hofer immersed himself in local politics. Partisan politics in Clayton County were more competitive than in much of Iowa, with a loosely organized local Republican party increasingly threatened by the Democrats. According to a report in the Clayton County Journal, the fractious 1878 Republican congressional convention, which met at McGregor's Atheneum, required an incredible 326 ballots to nominate Thomas F. Updegraff. The following year the Iowa State Register commented on the "strangeness" of Clayton County politics, while the McGregor News railed against "back room" deals in "packed" local Republican party conventions, which resulted in choosing candidates with "muscle instead of brains." 21

In the fall of 1882, Luman Hamlin "Calamity" Weller harnessed a coalition of Greenbackers and irregular Democrats and defeated Congressman Updegraff, while the regular Democrats carried most of the local offices. A few weeks after the elections, Hofer warned Senator Allison in a long letter that if the party were "left in a disorganized mass, a prey to bad man-

20. Hofer to Allison, 24 December 1882, Allison Papers.

21. Clayton County Journal, 4 September 1878; Iowa State Register, 20 July 1879; McGregor News, 23 July 1879, reprinted in Iowa State Register, 25 July 1879 . 
agement and irresponsible individuals and the offices given to Democrats and weak-kneed Republicans-you may look for nothing but defeat. In all these respects the party has been scandalously managed hereabouts." Not only were "aliens and enemies" occupying local political offices, but the "one-eyed widower" who served as postmaster of McGregor "dare not say his soul is his own in any question and ... has no politics that anyone has ever heard of." For Hofer, the only hope was a "complete reorganization of the party and with campaign work from the ground up and upon a national platform of action." $\mathrm{He}$ did not offer any specific political planks, however. ${ }^{22}$

Despite misgivings about the future of the Republican party, Hofer threw himself into the 1883 campaign, which became heated after the Iowa Supreme Court declared the prohibition amendment unconstitutional on a technicality. As one of the "Prohiblicans," the twenty-eight-year-old editor engaged in a series of eight debates on prohibition and other issues with Democratic County Treasurer C. E. Floete. The most memorable encounter occurred September 14 at the Clayton County Courthouse in Elkader. Years later, Hofer recalled that he had won the Elkader debate when he alluded to Floete's "dam roaring" - a reference to the sound of a mill dam on the Turkey River just outside the courthouse. The Democratic Elkader Register, however, contemporaneously reported that "Mr. Hofer is no match for Mr. Floete in such a discussion, but we must give him credit for bravely attempting to defend the rotten planks of protective tariff and prohibition in the republican platform." Just prior to the election, the News charged that the floating debt of the county was excessive. "Let us teach the syndicate of tax-collectors," Hofer cried, "that they cannot mulct the tax payers whenever they see fit." Treasurer Floete replied in the Elkader Register that the "whole tribe of Hoferites" were "snarling curs." According to Floete, Ernst Hofer's "wooden shoe intellect was undoubtedly yet saturated with the fusil oil emit-

22. Hofer to Allison, 24 December 1882,7 November 1883 . On the Iowa Greenback party and its fusion with Democrats, see Haynes, Third Party Movements, chaps. 12 and 13; and Colbert, "Political Fusion in Iowa." 
ted from the Littleport still; a clear case of how the transgressions of the father are visited on the son." 23

With the victory of the Democratic ticket in Clayton County, the Elkader Register snickered that the "McGregor News can now say 'I told you so,' for it predicted the defeat of the republican ticket two weeks ago." Hofer subsequently spelled out his frustrations to Allison. According to Hofer, Judge Reuben Noble, a Democrat who was connected to the powerful Chicago, Milwaukee, and St. Paul Railroad, was manipulating the local Republican party and backing a possible bid by Thomas Updegraff to regain his congressional seat. "Tom's candidacy, under the management of Noble and the championship of the Milwaukee corporation managers would only result in failure," Hofer pleaded, "and if allowed will only achieve the total annihilation of Tom and the Republican party in this corner of Iowa." An account in the Iowa State Register confirmed that, although the Fourth Congressional District in northeast Iowa was considered so safe that no great canvasses were made in 1882, the following year "nearly all organized effort was abandoned on the part of the Republicans" due to "unusual apathy in the Republican ranks." Hofer was not afflicted with apathy, but he did briefly train for a career in law before committing himself irrevocably to journalism. ${ }^{24}$

As the 1884 political campaign geared up, Hofer revealed the wide variety-in fact, the kaleidoscopic nature-of his causes. "This year," he advised readers of the News, "the republicans will have to fight the fiatists, the fusionists, the bourbons, the solid south, the free-traders, the whole beer and whiskey power, the communists and the monopolies." There were those who were convinced that Hofer was seeking some high political

23. Price, History of Clayton County, Iowa, 1:241-42; Lariat 2 (September 1923), 336; Elkader Register, 21 September 1883; McGregor News, 3 October 1883, quoted in Elkader Register, 25 January 1884; Elkader Register, 8 February 1884.

24. Elkader Register, 12 October 1883; Hofer to Allison, 7 November 1883, Allison Papers; Iowa State Register, 22 March 1884. On Hofer's foray into law, see Hofer to Allison, 19 January, 13 March, and 12 June 1884, Allison Papers; North Iowa Times, 19 July 1883. For several months during the early part of 1884, A. F. Hofer may have functioned as de facto editor of the McGregor News while Ernst was reading law. North Iowa Times, 7 February 1884. 
office. When he accused Congressman "Calamity" Weller of "more campaign skull-duggery than the average Democrat," W. P. Eno responded in a letter to the Elkader Register. "Is that paragon of political virtue and sagacity, Hofer, trying to scare all the republican candidates from the field," asked Eno, "that he may pick up our Tom [Updegraff]'s mantle and smite the Red Sea of the opposition, that he may walk over to congress dry shod?" Hofer didn't assume the guise of either Moses or Updegraff, but he did go on the hustings that fall on behalf of the party-despite his private feeling that G.O.P. national standard-bearer James G. Blaine was the "most corrupt man in the party." At great rallies around the state addressed by Republican notables and attended by party cohorts known as "Plumed Knights," Hofer added what one newspaper termed "wit and wisdom." Despite the hoopla, there were political winds of change blowing statewide and nationally. One scholar has noted that "James S. Clarkson [later] recalled the politicians' surprise in 1884 when the 'brass band, the red light, and the mass meeting seemed suddenly to have lost their power.'" Iowa did fall into the Blaine column, and Republican William E. Fuller recaptured Updegraff's congressional seat from "Calamity" Weller; but Grover Cleveland was elected the first Democratic president in nearly thirty years, and the Democrats decimated the Republicans in the northeast corner of the state. ${ }^{25}$

A splendid opportunity presented itself in 1885 when William Larrabee decided he would make another try for the gubernatorial nod. Holding title to two hundred thousand acres in Iowa, Larrabee was the largest landowner in the state, but according to the McGregor News the candidate was "not a typical 'rich' man.... In short he is a man who uses his wealth more for the benefit of others than himself." After Larrabee's nomination, the North Iowa Times described him as a "fair representative of the Clarkson dynasty, which allowed his nomination at the price of his vote for the prohibitory law [of 1884] in

25. McGregor News, quoted in Elkader Semi-Weekly Register, 11 April 1884; Elkader Semi-Weekly Register, 8 April 1884; North Iowa Times, 25 September 1884; Postville Review, 25 October 1884; Robert D. Marcus, Grand Old Party: Political Structure in the Gilded Age, 1880-1896 (New York, 1971), 61. For additional background on the national election of 1884, see John M. Dobson, Politics in the Gilded Age: A New Perspective on Reform (New York, 1972). 
the legislature." Narrowly elected governor in November 1885, Larrabee spent two consecutive two-year terms upholding prohibition, pushing through the abolition of the railroad pass system, and establishing maximum passenger and freight rates on railroads. ${ }^{26}$

Larrabee's election initially brought a small but tantalizing dividend to Hofer, for on January 12, 1886, the state senate voted 30-17 along party lines to choose him as its first assistant secretary. Donald D. Donnan, editor of the Clayton County Journal in Elkader, was elected secretary of the senate. Years later former state representative George $\mathrm{H}$. Van Houten reminisced that both Hofer and Donnan hailed from "beyond the Larrabee preserves." A contemporary correspondent of the North Iowa Times satirically observed that "Don rather overshadows his older assistant of the News, who with his usual sangfroid and a becoming modesty maintains his serenity of soul, and only regrets that he had not provided himself with as influential a father as young Donnan did." There was some truth in this assertion, as illustrated by a letter Hofer wrote to Lucy Maynard Salmon. "You will see," he exclaimed, "that I have a minor position [in the senate], tho' I have been acting Secy. for several weeks. A Senator's son of 23 secured the first Secretaryship, for which I was not a candidate, as I came down here more to learn the methods of legislation than I did for the purpose of gaining political honors." While the senate sat for its January-April session, Hofer wrote some letters to the McGregor News, at least one of which was highly critical of leading Democratic state senators. "The great trouble is," exclaimed the Waukon Democrat, "the child is afflicted with the big head to an alarming extent and ought to be placed in a box stall, fed on ground food and have his head bandaged with cowdung poultices to reduce the enlargement. He's got it bad."27

26. Henry Follett, interview with author, Clermont, Iowa, 3 July 1987; McGregor News, reprinted in West Union Weekly Republican Gazette, 20 March 1885; North Iowa Times, 3 September 1885. For an overview of Larrabee's administration, see Sage, A History of Iowa, 204-8; Rebecca Christian, "William Larrabee: Iowa's Outspoken Crusader for Reform," Iowan 32 (Winter 1983), 11-16, 52-53.

27. George H. Van Houten, "Response to Address of Welcome," in David C. Mott, "Pioneer Lawmakers Association," Annals of Iowa 16 (1929), 590; North 
The prohibition issue provided a golden opportunity for advancement. On May 3, 1886, the governor issued a proclamation urging public officials to enforce the temperance law the legislature had passed two years earlier. According to Larrabee, clergymen, teachers, and the press should "use their best efforts to enlist the moral forces of the State in this cause." No German-language newspaper in the state printed the proclamation, prompting Hofer to chide in the McGregor News that German publishers "seem to have great fears of permitting their readers to hear anything but one side of the question." This was not just rhetoric. On May 21, 1886, the Iowa State Register carried the following item: "One half of the five thousand [subscriptions] asked for, to enable the publishers to get out a firstclass German weekly at a low price, are assured." Ernst Hofer was about to launch a newspaper in Des Moines. ${ }^{28}$

\section{THE JOURNALISTIC SCENE IN DES MOINES was var-} ied and colorful, for the city then boasted nearly three dozen newspapers and magazines. Besides the seemingly omnipotent Iowa State Register, the dailies included the intensely Democratic Des Moines Leader and the independent and mildly Republican Daily Iowa Capital. The Leader, edited by John Watts, had suffered a disastrous fire on May 25, but in late June it occupied new quarters. On July 3, R. G. Orwig, "one of the most logical and forceful writers in the State," began his tenure as editor of the Capital. Among the dozen or so weeklies were the Iowa Homestead, edited by outspoken ex-minister Henry C. Wallace; the Swedish-language Svithiod; and the Democratic Germanlanguage Iowa Staats-Anzeiger, edited by Joseph Eiboeck. A former editor of the Republican Clayton County Journal and longtime personal friend of A. F. Hofer, Eiboeck had joined the Republican ranks over the issue of prohibition. Outside of Des Moines, there was a thriving German-language press, including

Iowa Times, 4 February 1886 (Donnan's father, W. G. Donnan, had served in congress and in the state senate); Hofer to Lucy Maynard Salmon, 27 March 1886, Salmon Papers; Waukon Democrat, quoted in North Iowa Times, 3 July 1886. The Iowa State Register, 3 December 1885, endorsed Hofer's quest to serve as assistant secretary.

28. Elkader Weekly Register, 6 May 1886; McGregor News, reprinted in Iowa State Register, 14 May 1886; Iowa State Register, 21 May 1886. 
the Davenport Demokrat, edited by John Peter Stibolt, and the Elkader Nord Iowa Herold, edited by Charles Reinecke. Hofer's entrance into the ranks of Des Moines journalists and headlong march into the prohibition brawl with the Germans marked the culmination of many years of hard work. ${ }^{29}$

On July 9, 1886, the first issue of Hofer's Iowa StaatsZeitung appeared. In common with and in imitation of the Iowa Staats-Anzeiger, the Staats-Zeitung offered three columns of English articles and editorials on the front page, but according to Staats-Anzeiger editor Joseph Eiboeck, the new paper had "patent insides," with half of each issue "printed in the East." This "boiler plate" was not unusual. "As early as 1883," writes Carl Wittke, "several firms in Philadelphia and Chicago carried on a prosperous business in furnishing stereotype as filler for the inside pages of German papers, especially weeklies." Seemingly indefatigable, Hofer commuted by train to McGregor each week via Dubuque, prompting the Daily Capital to term him the "travelling editor" of the News. ${ }^{30}$

In the first issue of the Staats-Zeitung, Hofer proclaimed that the paper's mission was to "correct the 'evil' habits and customs of the Germans," that is, their indulgence in intoxicating beverages. These words were not designed to build bridges of understanding, but the Daily Iowa Capital argued that the Staats-Zeitung had the "laudable purpose of meeting an evident demand for pure Iowa Republicanism in the purity and strength of the German language." Predictably, the Des Moines Leader was less charitable, commenting that the alleged "very large paid up subscription" was evidence that the "republican campaign committee must have dealt very liberally with it." The Nord Iowa Herold dismissed the Staats-Zeitung as "Dot Sharman Baper." 31

29. Bushnell's Des Moines Directory (Des Moines, 1886), 739; Will Porter, Annals of Polk County, Iowa, and City of Des Moines (Des Moines, 1898), 48384; Iowa Staats-Anzeiger, 1, 8 July 1886; Carl Wittke, The German-Language Press in America (Lexington, KY, 1957), 97.

30. Iowa Staats-Anzeiger, 15 July 1886; Wittke, German-Language Press, 219; Daily Iowa Capital, 30 November 1886.

31. Nord Iowa Herold and Iowa Staats-Zeitung, 9 July 1886, quoted in Iowa Staats-Anzeiger, 28 October 1886; Daily Iowa Capital, 10 July 1886; Des Moines Leader, 11 July 1886. 
Perhaps the most important challenge Hofer and the Republican party faced was the collective German presence of Theodore Guelich, former editor of the Republican Burlington Gazette, Stibolt of the Davenport Demokrat, and Eiboeck of the Staats-Anzeiger. The influential Guelich, founder of the Davenport Demokrat and the Burlington Herold, had returned to the Democratic fold as "leader of the revolt of the river cities against the prohibition law" and now advocated local option as an antidote to prohibition. On July 23, 1886, the third issue of the Staats-Zeitung carried a provocative editorial titled "By This Sign We Conquer?" in which Hofer-without naming themtook Guelich, Stibolt, and Eiboeck to task for misleading Germans regarding the local option plank. "They invite all German-Americans to hang their Personal Liberty garment on a peg and put on the local option straight jacket," claimed Hofer, "that they may vote the Democratic temperance ticket." Hofer thought Guelich, Stibolt, and Eiboeck had tried to entice Germans to vote Democratic by offering watered-down versions of prohibition. "What matters," Hofer argued, "by what conjuration we coax the fanatical slough-water prohibitionists into the Democratic camp, so we get there, says the Mephisto to his German American readers." In a subsequent editorial aimed at the "beer dripping editorials" of this "triumvirate of personal liberty in Iowa," Hofer derided "saloon-king Theodore" Guelich, "modern Theoderic" Stibolt, and "Crown-prince Joseph [Eiboeck] of Des Moines." Hofer's tactics were bound to strike a responsive chord. Wittke writes, "Many editors of the Germanlanguage press ... regarded the inroads of the white-ribbon hordes of fanatical prohibitionists upon their personal liberty as the major issue in recent American politics." The issue of personal liberty galvanized the German press nationally, but Eiboeck initially tried not to take Hofer too seriously. ${ }^{32}$

If he sometimes ignored Hofer's jibes on the issue of local option, Eiboeck did not keep silent when the Staats-Zeitung

32. Iowa State Register, 11 July 1885; Iowa Staats-Zeitung, reprinted in Iowa State Register, 24 July 1886; Iowa Staats-Zeitung, reprinted in Daily Iowa Capital, 12 August 1886; Wittke, German Language-Press, 164; Iowa StaatsAnzeiger, 19 August 1886. On Guelich, see also Iowa Staats-Zeitung, reprinted in Iowa State Register, 1 October 1887; and B. F. Gue, "Life and Death of Theodore Guelich," Annals of Iowa 1 (1893), 46-52. 
discussed the case of Rev. George Haddock, an outspoken prohibitionist allegedly murdered by German saloon elements in Sioux City in August 1886. The Democratic Leader deplored the murder, but Hofer and some Republicans sought to portray the incident in charged racial terms. For Hofer, the murder had "touched the German element with bloody fingers and left a stain that only future conduct can remove." Unwilling to concentrate his fire on Ernst, Eiboeck derided his erstwhile ally A. F. Hofer-also a prominent leader in the prohibition fightas a "slanderer of his race," an "infamous falsifier," and a "political traitor." The Staats-Anzeiger tartly concluded, "You are not worthy to be spit upon by your countrymen." Shortly, Eiboeck launched another attack. "Whatever faults German-Americans may have," he fulminated, "they have few traitors among them as Hofer and the bigots of the German Methodist churches." The Daily Capital felt prompted to answer, "Their [the Hofers'] crime is obedience to the laws of their country; Mr. Eiboeck's virtue is disobedience to those laws." ${ }^{\prime 3}$

Evidence of a sagging Republican party was mounting across Iowa, but the Iowa State Register blithely trumpeted, "Many thousands of Germans in Iowa are of [sic] the most determined enemies of the rum power." As one contemporary historian later noted, "By this time many of the citizens of the city [Des Moines] and county had become thoroughly disgusted with the prohibitory law and especially the manner of its attempted enforcement." According to the Elkader Register, there were only two Germans present at the 1887 Republican state convention, A. F. Hofer and J. Fred Meyer of Denison. "Verily," the Register clucked, "the German voter is no longer appreciated in the republican party and the Germans seem to understand it." In contrast to his repeated warnings about the health of the Republican party in 1882 and 1883, Ernst Hofer, perhaps caught up in the fervor of the moment, seemed strangely oblivious to the ominous clouds now gathering. When a respected Spillville farmer named Fritz Glass returned

33. Iowa Staats-Zeitung, quoted and answered, Iowa Staats-Anzeiger, 28 October 1886; Daily Iowa Capital, 13 November 1886. See also Thomas S. Smith, "A Martyr for Prohibition: The Murder of Reverend George C. Haddock," Palimpsest 62 (1981), 186-93. 
a complimentary copy of the Staats-Zeitung because he did not want to read anything produced by "purchased traitors of German principles," Hofer lampooned Glass as a "drunken foolish ass, whose highest idea of personal liberty is a beer-cask, whiskey bottle and gaming table." ${ }^{\text {"34 }}$

Cnice word

EVEN in the midst of the donnybrook over prohibition, Hofer involved himself in his usual outspoken fashion with other state and national issues, usually in letters to the McGregor News penned on the train. Early in 1887 it became apparent that Governor Larrabee would not reappoint Judge James W. $\mathrm{McDill}$ to the state railroad commission, in part because certain factions within the Republican party-including James S. Clarkson and his "Regency" - may have wished his removal. The Des Moines Leader reported that the "Des Moines correspondent of the Cedar Rapids Republican, who is [close] to the regency . . . , is apparently opposed to McDill, for the reason that his reappointment would suggest that but one generation of Iowa politicians is competent, qualified, worthy and intended to direct the affairs of Iowa." According to this theory, Clarkson and his regency might compel the retirement of McDill in order to make room for younger, more "progressive" men who might be more receptive to railroad interests. The Keokuk Daily Gate City had warned that the "commissioners are now, practically, in the hands of the railroads," but the treatment of McDill nevertheless raised Hofer's hackles. "We are in an age of mush and cowardice," cried Hofer in an especially graphic letter to the McGregor News. "If the Republican party is to go down on it[s] knees and belly in this way, and cowardly pander to its enemies, and more cowardly cast out its friends at the dictation of its enemies, it is time for it to die. There may be reasons for a change in railroad commissioners, but if it is done, it should be done for frank and self-respecting party reasons, and not to punish a good and noble man for loyalty to his party, nor to reward tricksters, demagogues and traitors for betraying

34. Iowa State Register, 14 July 1887; Porter, Annals of Polk County, 486; Elkader Register, 1 September 1887; Nord Iowa Herold, quoting Fritz Glass and Iowa Staats-Zeitung, reprinted in North Iowa Times, 8 September 1887. 
and fighting the party." McDill removed himself from consideration, and Larrabee named State Senator G. S. Robinson to serve on the railroad commission, which seemed to assuage Hofer's feelings. ${ }^{35}$

Hofer identified with the progressive wing of the Republican party on another key issue in state and national politics as he continued his family's tradition of supporting women's rights. The Woman's Standard (Des Moines) reported in 1888 that the McGregor News was one of about ten Iowa newspapers that "devote special columns to women's interests under the care of some competent woman." In this case, the "competent woman" was Hofer's younger sister Anna-subsequently Andrea-who was becoming proficient at journalism. Ernst's stand in favor of woman suffrage once earned him the sobriquet "confidential advisor to the petticoat brigade!" Yet when Democratic State Senator Frank D. Bayless sponsored a bill in 1888 to require that female teachers be paid the same as male teachers, Hofer opposed the measure. "The News," twitted the Elkader Register, "favors equal rights for women voting, but when it comes to dollars and cents it doesn't want them to stand on an equal footing with the men. Consistency[,] thy name is not the McGregor News." Hofer replied that the bill would hurt women, singled out one profession, and was a "senseless, demagogic measure [which] never should be made law." He added that the News would support a bill that applied equally to all professions. ${ }^{36}$

Despite his independent streak, Hofer toed the party line on most matters of national partisan politics and economic policies. In 1886 he had been outraged that "Democratic civil service reform," which aimed at removal of federal officials for

35. Des Moines Leader, 22 March 1887; Keokuk Daily Gate City, 11 December 1886; McGregor News, reprinted in Iowa State Register, 5 March 1887. The James W. McDill Papers at the University of Iowa Libraries do not contain any insights on this episode.

36. Woman's Standard, reprinted in McGregor News, 13 June 1888; McGregor News, reprinted in Iowa State Register, 12 February 1887; North Iowa Times, 25 September 1884; Elkader Weekly Register, 15 March 1888; McGregor News, 28 March 1888. Two of Hofer's sisters, Andrea Hofer Proudfoot and Amalie Hofer Jerome, played a leading role in the kindergarten movement, while a third sister, Mari Ruef Hofer, achieved fame as a compiler of children's songs and pageants. 
"offensive partisanship," was an "idea unworthy of [the] American people." Hofer also lambasted the Democrats for trying to tamper with the protective tariff. "We have had a democratic house of congress," he charged, "that has been unrelenting in its efforts to overthrow the American protective system in the interest of a British revenue tariff." It then followed that Hofer was opposed to a large national debt and the moneyed interests allegedly benefiting from it. "They [President Cleveland and his cabinet] can array themselves on the side of the people," he wrote Allison, "or on the side of the bondholders, who want the interest burden perpetuated." 37

The Iowa press often discussed Hofer, albeit in a partisan or scornful vein. During one chat with the editor of the Democratic Cedar Rapids Gazette, Hofer remarked that the "question of anti-monopoly amounted to nothing, that it would not come up for years, that he had tried it and it was no go." Gleefully, the Des Moines Leader suggested, "Now that Mr. Hofer and the republican party realize the situation it is decided that it is better for anti-monopoly to be a 'go' than for the republican party in the state to 'go.'" That is, the Republican party would be better advised to push anti-monopoly as an issue than prohibition. When Hofer announced that he was opposing C. T. Granger for chief justice of the state supreme court in April 1887, the Waukon Democrat offered a humorous reply: "That settles Judge Granger's hash, unless he can prevail upon Hofer to cease hostilities. His opposition and influence are felt about as much as the kick of a half-grown fly." ${ }^{38}$

Hofer now had two outlets for his views on state and national issues, but his financial position was still insecure, especially since the future of the Staats-Zeitung was uncertain and also because of his growing family. On January 14, 1887, he wrote to Senator Allison that he had "really gone into it [the Staats-Zeitung] as a matter of personal pride.... I realize the necessity of doing something for myself beyond a mere living

37. McGregor News, ca. November 1886, McGregor Historical Museum; McGregor News, quoted in Elkader Weekly Register, 2 December 1886; Hofer to Allison, 19 July 1886, Allison Papers.

38. Cedar Rapids Gazette, quoted in Des Moines Leader and reprinted in Elkader Weekly Register, 17 February 1887; Waukon Democrat, 27 April 1887. 
in these my best years." In fact, noted Hofer, due to the newspaper's unprofitable status, he was not certain he could continue as editor over the long run. The solution, he suggested, was that he run for state printer. "I would like the office as much for the deep pride I feel in the printing craft as for the money there is in,itho' [ sic] on the last point I will say that the office is a very lucrative one, receiving in remuneration next to the pay of an United States Senator." Hofer was a practical journalist who was trying to cash in his political debts. "Those who bear a share in the labors of our state campaigns," he advised Allison in May, "are interested in the upbuilding of a strong German Republican party paper. We can with the help of this office make our paper as large and as strong a paper as the Register is for English readers." 39

In May the McGregor News argued that a "German Republican be given a place on the ticket" to help "identify the best element of our German people permanently with the Republican party." The Fayette Postal Card huffed that Hofer was an "offensive snob" who "is but doing the meanest, lowest, dirtiest work for his party-for the sake of the pay." As the campaign for state printer geared up in the fall of 1887 , Hofer appeared to have more than a fighting chance, despite the presence of several other candidates. "No young man," observed the Howard County Times in October, "has done more or better service for the Republican party and the temperance cause than has Ernst Hofer. ... His command of two languages and two papers has given him an influence that few possess." Hofer pleaded for party harmony, but he facetiously reported that St. Peter had chastised him during a dream for doing the "state a grievous wrong by praising every candidate for office in your own party." Shortly before the election, A. F. Hofer \& Sons mailed a statewide circular proclaiming that the McGregor News exercised an influence "due in large measure to the work and ability of one of its editors who is now a candidate. He has been a faithful and loyal worker for the party for many years." The circular did not detail its claims, because it presumed that many Iowans were familiar with the News through Hofer's

39. Hofer to Allison, 14, 29 January, 12 February, 25 May 1887, Allison Papers. 
fiery articles and letters, which were sometimes reprinted in the Iowa State Register and other newspapers throughout the state. Almost as an afterthought, the circular concluded, "Besides, he has a thorough and practical knowledge of the printing business." 40

As the legislature convened on January 9, 1888, political maverick James B. Weaver's Iowa Tribune noted that "there was a perfect swarm of candidates who wanted to be doorkeepers in the House of the Republicans." The joint Republican caucus to choose a party nominee for state printer, held on January 10 , aptly fit Weaver's description. Following the first ballot, the contest was clearly between Hofer and George H. Ragsdale, whom the Des Moines Leader had once caricatured as the able but "cadaverous looking quill driver of the LeMars Sentinel." The Sentinel itself described the rather chaotic scene at the caucus. "Friends of the candidates from the lobby rushed in among the official seats to plead for their man and there was something of a tumbling over desks and collisions which jostled the suspended dignity of the wise men." After five hotly contested ballots, the caucus chose Ragsdale over Hofer by a vote of $51-46 .{ }^{41}$

Shortly after his defeat, an exhausted Hofer sold the unprofitable Iowa Staats-Zeitung to P. J. Merkel, his less dynamic coeditor on the German enterprise, "retired" from politics, and thereafter took little interest in the cause of prohibition. The Fayette Postal Card exulted that Hofer was a "shortcoated spoopendyke (a foolish, subservient fellow) who had "gone back to Jericho to tarry till his beard starts." If Hofer's abandonment of the prohibition cause makes his earlier actions appear opportunistic, one must also conclude that he was disillusioned, tired, and probably low on funds after nearly two years of service on the Iowa Staats-Zeitung. Several years later, he concluded that the prohibition crusade in Iowa had "resulted

40. McGregor News, 11 May 1887; Fayette Postal Card, reprinted in Iowa Staats-Anzeiger, 21 July 1887; Howard County Times, reprinted in Iowa State Register, 15 October 1887; McGregor News, 7 December 1887; election circular from A. F. Hofer \& Sons, 12 December 1887, Allison Papers.

41. Iowa Tribune, 11 January 1888; Iowa State Register, 11 January 1888; Des Moines Leader, 23 August 1887; LeMars Semi-Weekly Sentinel, 20 January 1888 . 
in making great expense and not perceptibly diminishing the liquor traffic, but causing hard feelings between neighbors and communities." 42

Just after Hofer lost his bid for state printer, the Chicago Tribune reported that a shaken Hofer may have held Larrabee responsible for his loss-a charge the feisty editor denied. Hofer later reasoned that he had been "defeated by the combine," that is, Clarkson's "Regency." In fact, Larrabee and Clarkson were soon engaged in another battle with wideranging consequences. On January 12, 1888, the governor gave his second inaugural address, in which he asked the General Assembly to abolish railroad passes and establish maximum passenger and freight rates. Larrabee's speech highly agitated James S. Clarkson. "[James B.] Weaver and his demagogism has never equalled this," he fumed to Senator Allison. "He cares nothing for the party." Five years earlier, the News had strongly supported efforts by William and Frank Larrabee and others to construct a railroad from McGregor to Des Moines, as an antidote to the alleged stranglehold that the Chicago, Milwaukee, and St. Paul Railroad had on northeastern Iowa. Yet Hofer had never subscribed to the more extreme position on railroad regulation that James B. Weaver held. "The attempt of the Des Moines Register to make out that Governor Larrabee has adopted General Weaver's ideas," Hofer now charged, "will not succeed." That did not stop Clarkson from trying. Referring to the News as a "paper never afraid to express an opinion, nor to defend it afterwards," he replied that both Weaver's ideas and Larrabee's inaugural speech were "savage indictments" of the Republican party. Hofer subsequently admitted that some of Larrabee's previous actions had been "weak and indefensible" and argued that the state should not "assume the management of the railways in any degree." Clarkson was unable to sustain his position, and Hofer's fears of government control were somewhat assuaged after the state legislature unanimously approved a railroad commission that reduced all railroad rates

42. Strawberry Point Press, reprinted in North Iowa Times, 19 July 1888; McGregor News, 5 September 1888; Fayette Postal Card, reprinted in Iowa Staats-Anzeiger, 19 July 1888; Salem [Oregon] Weekly Capital Journal, 23 June 1904. 
by 20 percent without assuming any real control of the roads. It is interesting that Hofer was willing to support and yet affront the governor, but more fascinating that he now advocated the sanctity of railroads, despite many years of disparaging comments about corporations in general and railroads in particular. The only explanation is that, despite his displeasure with certain powerful carriers, Hofer may have been apprehensive that regulation of railroads might impede economic development, which was one of his perennial causes. ${ }^{43}$

During the Republican national convention that summer, Iowans waited with anticipation as Senator Allison, assisted by James S. Clarkson, made a serious bid for the presidential nomination, only to lose to Benjamin Harrison of Indiana. Ernst Hofer loyally supported Harrison and hawked the protective tariff, as he had for many years. "With protection in the interests of the wage-worker and our country," he urged, "we must, at the same time, have healthy competition in the interests of the whole people." Although Hofer stayed the Republican course, perceptive observers would have noticed that he was floating some warnings. On the eve of the 1888 national elections, the McGregor News announced that unless a political party supported a local newspaper with advertising and job printing, "it can only be a question of time when all publishers who can, will go into [an]other and more profitable business that does not require such constant sacrifices at the altar of party devotion, sacrifices which the private citizen, never feels called upon to make." Following Harrison's election, the Hofers unsuccessfully lobbied Larrabee for some kind of state or federal appointment and urged President Harrison to name James S. Clarkson to his cabinet. "At one time this winter," Ernst Hofer quipped, "we felt like offering ourselves to Prest.[-Elect]

43. Chicago Daily Tribune, 22, 26 March 1888; McGregor News, 29 May 1889; Clarkson to Allison, 13 January 1888, Allison Papers; McGregor News, quoted and answered in Iowa State Register, 3 February 1888; McGregor News, 8, 15 February 1888. See also John Lauritz Larson, Bonds of Enterprise: John Murray Forbes and Western Development in America's Railway Age (Boston, 1984), 183-95; and William Larrabee, The Railroad Question: A Historical Treatise on Railroads, and Remedies for Their Abuses (Chicago, 1898). On Hofer's earlier railroad efforts, see Elkader Register, 16 February 1883; West Union Republican Gazette, 9 March 1883; Realto E. Price to McGregor News, quoted in Elkader Register, 14 December 1883; North Iowa Times, 22 February 1883. 
Harrison for a cabinet position. . . We can see since that several self-sacrificing lawyers, (we presume with a small-paying practice) have offered to accept places and we feel relieved." ${ }^{\prime 4}$

The national G.O.P. may have reoccupied the White House after four years of Democratic rule, but an "overconfident and carelessly organized" Iowa Republican party unwittingly marched down the road to defeat. Many local Republican party leaders were unaccountably complacent, possibly since the Democratic majority in Clayton County had been halved as large numbers of Germans returned to the Republican fold during the 1888 election. Judge E. H. Williams of Postville gloated that Iowa had "now won three notable conflicts with democracy [the Democratic party] the saloon and the railroads." Hofer was a more astute political observer, warning that Germans "have the political destiny of our county in their hands in large measure." As the 1889 Iowa gubernatorial battle geared up, Hofer virtually ignored prohibition, urging Larrabee to run for a third term to continue the battle against the "corporation plutocrats" and their editorial minions, including Clarkson. "They have come to regard our state as a juicy piece of fruit," boomed the News, "created for the sole purpose of being squeezed dry by a little group of corporation managers in the interest of Chicago, St. Paul and a few other large business centers." The governor wisely declined to run for reelection. That November, German Republicans joined with the Democrats, a "motley collection of losers," to elect Horace Boies as the first Democratic governor of Iowa in nearly forty years. The once invincible Republicans had been vanquished, largely by prohibition. ${ }^{45}$

44. McGregor News, 31 October 1888, 27 February 1889; Larrabee to the President, 3 April 1889, Governor Letter Book, 8 January 1889-4 February 1890, Series GII, vol. 80, p. 302, State Historical Society of Iowa, Des Moines; A. F. Hofer \& Sons to Harrison, 24 January 1889, Benjamin Harrison Papers, Library of Congress.

45. Jensen, Winning the Midwest, 90; E. H. Williams to J. O. Crosby, 13 February 1889 , J. O. Crosby Papers, Garnavillo Historical Society, Garnavillo, Iowa; McGregor News, 28 November 1888; McGregor News, n.d. [pencil notation "1888," but context indicates early 1889], Larrabee Scrapbook, Larrabee Papers, Montauk. 
THE DOWNWARD SLIDE of the state Republican party, coupled with his own professional frustrations, impelled Hofer to leave Iowa. Armed with a strong letter of recommendation from Governor Larrabee, Hofer made a lengthy trip to the Pacific Northwest during the 1889 election campaign to look for business opportunities. Rejecting "flattering offers" to move to Seattle or Tacoma, Washington, Ernst and his brother Andrew bought the Salem [Oregon] Capital Journal, founded only the previous year. On the very December day that Ernst returned to McGregor to wind up his affairs, he wrote to Larrabee that he hoped to participate in the "upbuilding" of Oregon, including construction of "new railroads and new banks." Larrabee immediately invited him to serve briefly as his private secretary. The retiring governor and the young editor must have relished discussing their respective futures, the former looking forward to managing his lands and writing at his Montauk estate looking out over Clermont, the latter anxious to launch a new career in the Pacific Northwest. Then, in mid-January 1890, Ernst, his wife, and their two small children left Iowa, traveled to St. Paul by train and over the plains in a cold Northern Pacific Pullman car to the "rainy, misty valleys of western Oregon." ${ }^{46}$

Just before Hofer left, James S. Clarkson wrote that he had "won an enviable reputation, both for his strength as a political writer and his skill and grace as a general writer." The Iowa State Register-now edited by James's brother Richard-warmly allowed that Hofer was "capable of giving the Republicans of Oregon a stronger paper than that state has ever had." Both James and Richard Clarkson were mindful that Hofer did not always toe the party line and sometimes took a jaundiced view

46. Larrabee to Governor Sylvester Pennoyer, 13 May 1889, Governor Letter Book, 8 January $1889-4$ February 1890 , Series GII, vol. 80 , p. 395, State Historical Society of Iowa, Des Moines; Salem Weekly Capital Journal, 18 April 1890; Hofer to Larrabee, 23 December 1889, William Larrabee Papers, State Historical Society of Iowa, Iowa City; Elkader Register, 26 December 1889; Lariat 1 (February 1923), 46, 48. The bond between Ernst Hofer and the Larrabees lasted until the 1920s. Hofer to Larrabee, 11 August 1893, 30 May 1904, Larrabee Papers, Montauk; Mrs. Allan A. Bynon, interview with author, Lake Oswego, Oregon, 6 July 1973. A. F. Hofer sold the McGregor News to J. F. Widman on 21 April 1890 and later moved to Chicago, where he died in 1905. 
of the Register itself. "There is no criticism to be made of The Register," Hofer had recently editorialized, "except that it has been too devoted to the interests that have made Des Moines what it is, the natural course with any city paper." The McGregor News evidenced a curious mixture of praise and disdain for both James S. Clarkson and the Iowa State Register, which may be only partially explained by the undulations of Hofer's career. One key to this apparent vacillation may lie in the relationship that both A. F. and Ernst Hofer had with "Father" Clarkson, who was renowned for his resistance to the "extortions of the 'Barbed Wire Syndicate'" that had threatened farmers in the late 1870 s and early 1880 s. When Father Clarkson died in May 1890, Ernst Hofer recalled that his "ringing anti-monopoly sentiments could never be put down." Hofer never developed the admiration for James S. Clarkson that he evidenced toward Father Clarkson, because the younger Clarkson represented ideas that Hofer could not accept. It is also possible that some contradictions in News policy may be due to the fact that A. F. Hofer, who was listed as "editor" or "senior editor," occasionally wrote editorials, which were almost always unsigned, or that he prevailed upon his son to tone down or even alter some of his polemics. "The senior editor of THE NEWS," Ernst Hofer observed in 1889, "does not look upon lowa public men from quite as vinegarish a standpoint [as does the junior editor]." ${ }^{47}$

Ernst Hofer adhered to a journalistic code that sometimes placed him outside the pale of his own party and even thwarted his own ambitions. As he had recently observed, "If a party paper shuts its eyes to all defects in the public service so long as they are committed by men on its own side, it is of the least possible use to the people." He was undoubtedly aware that Henry Watterson of the Louisville Courier-Journal had advised, "The ideal editor need not be-nay, he must not be- neutral." Hofer relished his combative journalistic style, commenting in 1888

47. James S. Clarkson to M. L. Chamberlain, n.d. [ca. December 1889], reprinted in Salem Capital Journal, 23 January 1891; Iowa State Register, 26 January 1890; McGregor News, reprinted in Iowa State Register, 29 December 1889; "Recollections of C. F. Clarkson," Annals of Iowa 1 (1894), 411; Earl W. Hayter, "An Iowa Farmers' Protective Association: A Barbed Wire Protest Movement," Iowa Journal of History and Politics 37 (1939), 331-62; Salem Weekly Capital Journal, 16 May 1890; McGregor News, 13 February 1889. 
that "THE NEWS believes in the kind of Republicanism that sends sneaks, spies and dodgers to the rear." For Hofer, fellow editor George D. Perkins of the Sioux City Journal was admirable because he was one person who was not a "cringing sycophant." While certainly not of the stature of James S. Clarkson, Joseph Eiboeck, or-to quote Hofer's own words-the "poetic and epigramatic" Sam Clark of the Keokuk Gate City, Hofer was a controversial member of the Iowa journalistic community during one of its most vitriolic periods. Toward the end of his life, he mused, "Much of my work on this Iowa weekly [the McGregor News] was crude and raw and I was intolerant of others." 48

Any assessment of Hofer must take into account his ambition, his devotion to reform, and the milieu in which he lived. He was an Iowan on the make; as such his political and economic philosophy contained a strong element of opportunism, coupled with a genuine and fervent desire for political reform. Hofer sought opportunities by attaching himself to people or causes, but he was genuinely concerned about the aimless local Republican party. He demonstrated considerable courage by supporting prohibition when most Germans in Clayton County canceled their subscriptions to the News. Taking a comparatively unknown weekly newspaper in a small Mississippi River town that had known better days, Hofer fought myriad editorial battles and brought to the McGregor News a degree of influence-or notoriety. The Iowa State Register often copied articles from the News, although reprints from other larger city newspaper "exchanges," such as the Keokuk Gate City, Council Bluffs Nonpareil, Burlington Hawkeye, Marshalltown Republican, and Sioux City Journal, were more frequent. The Iowa StaatsZeitung represented a bold move on the part of Hofer and the Republican party to stem the defection of the Germans on the prohibition question, but even under Hofer's unflagging and uncompromising editorship, the paper did not succeed in its

48. McGregor News, reprinted in Iowa State Register, 29 December 1889; Louisville Courier-Journal, reprinted in Keokuk Daily Gate City, 13 October 1886; Joseph Frazier Wall, Henry Watterson: Reconstructed Rebel (New York, 1956); McGregor News, 28 November 1888, 13 February 1889; McGregor News, reprinted in Keokuk Daily Gate City, 18 December 1886; Lariat 1 (July 1923), 252. 
mission. Despite the important role it played in the events that led to the temporary overthrow of the Republican party in Iowa, historians have overlooked the Iowa Staats-Zeitung and its editor. Hofer's career is important because it sheds new light on the vicissitudes of the Republican party in portions of northeastern Iowa, and it illustrates the lengths to which the state party leadership was prepared to go to publicize and enforce prohibition. ${ }^{49}$

Hofer's antagonism toward certain "vested" interestscities, railroads, and political "combinations" — cemented by his comparative inability to attain a secure place in the "system," was buttressed by his family's financial struggles, particularly the painful financial reverses of 1872. In addition, neither he nor his family ever felt accepted by "society." In 1927 his sister, Mari Ruef Hofer, wrote to Lucy Maynard Salmon, "You always thought of us as sort of outlanders, not exactly in the circle." That "circle" included Rachel Larrabee, Ernst's classmate; her father Frank, the local banker; her uncle William Larrabee of Clermont; Judge E. H. Williams of Postville; and J. O. Crosby, a wealthy attorney from Garnavillo. "Father in his impulsive way," Mari Ruef Hofer further reminisced, "was always overstepping the New England-rather Yankee-reserve around him, then making the matter worse by trying to explain." The Larrabee brothers hailed from Connecticut, the most "Yankee" of all states, yet Ernst Hofer was greatly influenced and assisted by William Larrabee, a "pioneer" and a bold "experimenter" whose efforts anticipated some of the Progressive reforms of the twentieth century. Hofer's career, too, anticipated some of those same reforms. In Hofer's eyes, a good economic and political system was one that allowed anyone with talent and ambition to succeed, particularly worthy people from small cities and rural areas. Historian John G. Sproat could have had Hofer in mind when he concluded, "In the last analysis, good government meant government responsive to the demands of

49. An Iowa Staatszeitung did exist in Dubuque in the 1860 s. Wittke, GermanLanguage Press in America, 97. One scholar has postulated that the Democratic victory in the 1889 Iowa elections was due to the fact that "railroad influence was greater in the Democracy than in the Republican camp." Horace Samuel Merrill, Bourbon Democracy of the Middle West, 1865-1896 (Seattle, 1967), 179-80. 
those who clamored for it." Although Sproat was referring to the Mugwumps-largely upper-class eastern reformers whom Hofer abhorred - the feisty editor might have accepted the assessment. ${ }^{50}$

"Among the components of crisis," wrote historian Robert $\mathrm{H}$. Wiebe of the "search for order" in the late nineteenth century, "none found fuller expression than the belief that great corporations were stifling opportunity, and no one cried his resentment more persistently than the local entrepreneur." In this, at least, Ernst Hofer was a typical local entrepreneur of the Gilded Age. He was a fervent believer in individualism-except when applied to prohibition or political patronage-and he consistently fought those forces he believed thwarted the individual's path to success and self-fulfillment. It was a futile battle against the pervasive trend toward economic concentration. "The single most significant phenomenon in modern American history," writes Louis Galambos, "is the emergence of giant, complex organizations." Hofer's acquaintance James S. Clarkson showed that he at least implicitly understood that development when he left the Iowa State Register in 1888 to lead what Richard Jensen terms the "merchandising" or "stylistic reorientation within the GOP." Hofer himself, however, did not accept or understand what he was up against for many years. Shortly after his defeat for state printer, a chastened Hofer spelled out his personal philosophy: "Divest yourself of dreams, young man or woman, and go to work with a determination that so far as the powers are given you, you will be the architect of your own fortunes. ${ }^{\prime 51}$

50. Mari Ruef Hofer to Lucy Maynard Salmon, 13 February 1927, Salmon Papers; Haynes, Third Party Movements, 441; Larson, Bonds of Enterprise, 185-205; John G. Sproat, "The Best Men": Liberal Reformers in the Gilded Age (New York, 1968), 245. The dozens of letters between Rachel Larrabee and Lucy Maynard Salmon, in the Salmon Papers, provide an intriguing illustration of "society" in Clayton County during the Gilded Age and after. On "disinterested reformers," see also Dobson, Politics in the Gilded Age, 84; Ari Hoogenboom, "Spoilsmen and Reformers: Civil Service Reform and Public Morality," in H. Wayne Morgan, ed., The Gilded Age: A Reappraisal (Syracuse, 1963), 80.

51. Robert H. Wiebe, The Search for Order, 1877-1920 (New York, 1967), 45; Louis Galambos and Barbara Barrow Spence, The Public Image of Big Business in America, 1880-1940: A Quantitative Study of Social Change (Baltimore and 
Hofer's Iowa years are less enigmatic when viewed through the prism of his extended-and better documentedOregon career. During his predictably boisterous tenure at the Salem Capital Journal from 1890 to 1912, Hofer became a familiar and eccentric fixture on the Oregon scene. During that period, he befriended wealthy silver mine owner Jonathan Bourne, bolted the Republican party over free silver, published a pamphlet titled The School of Politics: The American Primary System (Chicago, 1896), was disinclined to support William S. U'Ren and his "Oregon System," and tried to promote a railroad from Coos Bay, Oregon, to Boise, Idaho. A disastrous run for the Republican gubernatorial nomination in 1910 effectively ended his political aspirations. Henry Sheldon, dean of the University of Oregon School of Journalism, later termed Hofer a "shrewd and aggressive journalist of buoyant personality who combined sensational methods with a long eye for the main chance." After the founding of the investment and editorial marketing firm of E. Hofer \& Sons in 1911, he prospered by fervently embracing the private enterprise system that spawned industrial giants-particularly utilities. Through their boiler plate editorials sent out to more than ten thousand weekly newspapers, as well as through the pages of their monthly Manufacturer and Industrial News Bureau, E. Hofer \& Sons had by the 1920 s become anathema to progressive reformers. Although he ended his career as a wealthy proponent of industrial growth, Hofer never wavered in his opposition to "officious" government, political "combinations," and big cities. If his early years are important for what they tell us about journalism and party politics in Iowa, his entire career illustrates an evolving conservatism that had its roots in "spicy" service on a "small country weekly" in McGregor, Iowa. ${ }^{52}$

London, 1975), 3; Jensen, Winning of the Midwest, 165, 171; McGregor News, 20 February 1889. Hofer also did not grasp the "shared world" of city and country so brilliantly described recently by William Cronon in Nature's Metropolis: Chicago and the Great West (New York and London, 1991), 51.

52. Henry D. Sheldon, History of the University of Oregon (Portland, 1940), 143; Rolf H. Swensen, "'An Age of Reform and Improvements': The Life of Col. E. Hofer (1855-1934)" (Ph.D. diss., University of Oregon, 1975). 
Copyright of Annals of Iowa is the property of State of Iowa, by \& through the State Historical Society of Iowa and its content may not be copied or emailed to multiple sites or posted to a listserv without the copyright holder's express written permission. However, users may print, download, or email articles for individual use. 